\title{
EVALUASI PENERAPAN PAJAK PENGHASILAN PASAL 21 MENURUT PMK NOMOR 262/PMK.03/2010 DAN PERATURAN DIRJEN PAJAK NOMOR 16/PJ/2016 PADA INSPEKTORAT DAERAH KABUPATEN MINAHASA SELATAN
}

\author{
Lady M. Johannis ${ }^{1}$, Jullie J. Sondakh ${ }^{2}$, Dhullo Afandi ${ }^{3}$ \\ 1,2,3 Jurusan Akuntansi, Fakultas Ekonomi dan Bisnis, Universitas Sam Ratulangi, Jl.Kampus Bahu. Manado, \\ 95115, Indonesia
}

Email : meriamjohannis@yahoo.com

\begin{abstract}
To establish an equal national development, funds are needed to be the financial resources. Income tax is acknowledged as one of the most potential financial resources. Tax is a contribution of assessable to the state without acquiring direct reciprocal services (contraprestation) and forceful under the law. Income tax section 21 is subjected to incomes for intance, salary, honorarium with different names associated to the employment, and individual services or positions. The purpose of this research is to evaluate whether the computation, deposit and report of Income Tax Section 21 at Regional Inspectorate of South Minahasa Regency are adequate according to conditions in PMK 262/PMK.03 Year 2010 and the Regulation of General Directorof Tax Number PER-16/PJ/2016. Analitycal method used in this study was descriptive method. According to the study finding, it can be concluded that the computation and deposit of Income Tax Section 21 implemented by the Regional Inspectorate of South Minahasa Regency is sufficient according to applied conditions in PMK 262/PMK.03 Year 2010. However, the Income Tax Section 21 report implemented by the Regional Inspectorate of South Minahasa Regency is unsatisfactory according to applied conditions in the Regulation of General Director of Tax Number PER-16/PJ/2016 because the expenditure treasurer did not report the Income Tax Section 21 closing.
\end{abstract}

Keywords: income Tax Section 21, Computation System, Truncation System, Deposit System and, Report System.

\section{PENDAHULUAN}

Indonesia mempunyai potensi penerimaan pajak dari pajak penghasilan karena hampir semua orang maupun organisasi dalam melaksanakan aktifitasnya semata-mata untuk memperoleh penghasilan atau keuntungan. Bagi Indonesia pajak penghasilan merupakan potensi karena jumlah penduduk Indonesia adalah sebanyak 263.846.946 juta jiwa pada tahun 2016, yang tersebar di 17.504 pulau. Pajak Penghasilan Pasal 21 adalah pajak yang dipotong oleh pemberi kerja atas penghasilan yang dibayar kepada orang pribadi sehubungan dengan pekerjaan yang dilakukan kepada pemberi kerja.

Inspektorat Daerah Kabupaten Minahasa Selatan merupakan suatu lembaga pemerintah yang dibentuk untuk melaksanakan penyelenggaraan pemerintah daerah di bidang pengawasan atau sebagai audit internal pemerintah berdasarkan dengan kebijakan yang ditetapkan oleh bupati. Penerapan PPh Pasal 21 di Inspektorat Daerah Kabupaten Minahasa Selatan dilakukan oleh bendahara pengeluaran.

Penerapan PPh Pasal 21 pada instansi pemerintah tidak lepas dari unsur kelalaian dan ketidakpatuhan oleh bendahara pengeluaran, maka penulis tertarik untuk mengadakan penelitian yang berjudul “ Evaluasi Penerapan Pajak Penghasilan Pasal 21 Menurut PMK Nomor 262/PMK.03/2010 dan Peraturan Dirjen Pajak Nomor PER-16/PJ/2016 Pada Inspektorat Daerah Kabupaten Minahasa Selatan". Penelitian ini bertujuan untuk mengevaluasi kesesuaian penerapan Pajak Penghasilan Pasal 21 pada Inspektorat Daerah 
Kabupaten Minahasa Selatan dengan PMK 262/PMK.03 Tahun 2010 dan Peraturan Dirjen Pajak Nomor 16/PJ/2016.

\section{TINJAUAN PUSTAKA}

Akuntansi Pajak. Akuntansi pajak adalah proses pencatatan akuntansi yang berpedoman pada ketentuan Undang - Undang Perpajakan yang nantinya akan menghasilkan laporan keuangan fiskal, yang diakui oleh pajak.

Pajak Penghasilan Pasal 21. Pajak Penghasilan Pasal 21 adalah pajak yang dipotong oleh pemberi kerja atas penghasilan yang dibayarkan kepada orang pribadi sehubungan dengan pekerjaan yang dilakukan kepada pemberi kerja. Menurut UU No.36 Tahun 2008 Pasal 21 penghasilan yang dimaksud meliputi tunjangan, upah, gaji, honorarium dan pembayaran dengan nama dan bentuk lainnya.

\section{Pajak Penghasilan Pasal 21 yang Dipotong Bendahara Pemerintah}

Kategori Penerima Penghasilan. Penerima penghasilan yang wajib dipotong PPh Pasal 21 oleh bendahara pemerintah sesuai dengan Peraturan Menteri Keuangan Nomor 262/PMK.03 Tahun 2010 adalah:

1. Pegawai, yaitu meliputi Pegawai Negeri Sipil atau Calon Pegawai Negeri Sipil, Pegawai Magang, Anggota Tentara Negara Indonesia, Anggota Polisi Republik Indonesia, Pegawai Tidak Tetap dan Pegawai Honorer.

2. Bukan pegawai, misalnya orang yang menjadi pembicara dalam suatu kegiatan ataupun orang yang memberi jasa (misalnya : tukang service AC kantor).

3. Yang menjadi peserta sehubungan dengan suatu kegiatan yang diadakan oleh instansi pemerintah.

\section{Perhitungan PPh Pasal 21}

Dasar Pengenaan PPh Pasal 21. Dasar Pengenaan Pajak PPh Pasal 21 yang tidak final atas penghasilan yang diterima secara tetap dan teratur untuk setiap bulan, sesuai dengan Peraturan Menteri Keuangan Nomor 262/PMK.03 Tahun 2010 adalah Penghasilan Kena Pajak (PKP). Alur perhitungannya dimulai dari perhitungan penghasilan bruto yang didapat dari penjumlahan gaji pokok dan tunjangan yang diterima setiap bulan kemudian penghasilan bruto dikurangi dengan biaya jabatan/biaya pensiun dan iuran pensiun/iuran tunjangan hari tua (THT), maka didapat penghasilan neto sebulan, kemudian di kali 12 untuk mendapat penghasilan neto setahun. Penghasilan neto setahun dikurangi dengan Penghasilan Tidak Kena Pajak (PTKP) maka didapat Penghasilan Kena Pajak (PKP) yang merupakan dasar pengenaan pajak (DPP) PPh Pasal 21. Sedangkan untuk penghasilan yang diterima secara tidak tetap dan tidak teratur dikenakan pajak final yang tarifnya disesuaikan dengan golongan pegawai yang bersangkutan dan yang menjadi dasar pengenaan pajak (DPP) adalah penghasilan bruto.

Pengurangan Yang Diperbolehkan. Dalam PMK 262/PMK.03 Tahun 2010, menyatakan bahwa pengurangan yang diperbolehkan dalam menghitung besarnya PPh Pasal 21 yang terutang adalah sebagai berikut :

1. Biaya Jabatan, batas yang diperkenankan untuk biaya jabatan adalah 5\% (lima persen) dari penghasilan bruto dan setinggi - tingginya Rp.6.000.000 per tahun atau Rp.500.000 per bulan.

2. Biaya Pensiun, yang dikurangkan adalah biaya pensiun yang dibayar kepada seorang pensiunan secara bulanan.

3. Iuran yang Terkait dengan Gaji, yaitu iuran yang dibayar kepada lembaga yang disahkan oleh Menteri Keuangan, lembaga tersebut berupa lembaga pensiun atau badan penyelenggara hari tua. 
4. Penghasilan Tidak Kena Pajak (PTKP) adalah batasan penghasilan yang akan dikenakan PPh Pasal 21. Jadi untuk penghasilan dibawa PTKP tidak dikenakan Pajak PPh Pasal 21.

Tabel 1. Batasan Penghasilan Tidak Kena Pajak (PTKP) Berdasarkan PMK.NO.101/PMK.010/2016

\begin{tabular}{|c|c|}
\hline Batasan PTKP & \multicolumn{1}{c|}{ Keterangan } \\
\hline Rp54.000.000,00 & Wajib Pajak Orang Pribadi \\
\hline Rp4.500.000,00 tambahan & Wajib Pajak Kawin \\
\hline Rp4.500.000,00 tambahan & $\begin{array}{l}\text { untuk setiap orang yang menjadi tanggungan Wajib } \\
\text { Pajak, dihitung hingga tanggungan ke-3. }\end{array}$ \\
\hline
\end{tabular}

\section{Tarif PPh Pasal 21}

1. Atas penghasilan yang dikenai PPh yang tidak bersifat final dikenakan pajak progresif sesuai dengan Pasal 17 UU PPh adalah sebagai berikut :

Tabel 2. Besaran Tarif PPh WPOP Sesuai Pasal 17 UU No.36 Tahun 2008

\begin{tabular}{|l|c|}
\hline \multicolumn{1}{|c|}{ Lapisan Penghasilan Kena Pajak } & Tarif \\
\hline$<\mathrm{Rp50.000.000,00}$ & $5 \%$ \\
\hline $\mathrm{Rp} 50.000 .000,00-\mathrm{Rp} 250.000 .000,00$ & $15 \%$ \\
\hline $\mathrm{Rp} 250.000 .000,00-\mathrm{Rp} 500.000 .000,00$ & $25 \%$ \\
\hline$>\mathrm{Rp} 500.000 .000,00$ & $30 \%$ \\
\hline
\end{tabular}

2. Atas penghasilan yang dikenai $\mathrm{PPh}$ yang bersifat final berupa honorarium atau imbalan tidak tetap dan teratur lainnya yang menjadi beban APBN atau APBD dan dibayarkan kepada PNS (termasuk CPNS) berdasarkan PP No 80 Tahun 2010 adalah sebagai berikut:

a. $0 \%$ dari penghasilan bruto dikenakan kepada pegawai dengan golongan I dan II.

b. 5\% dari penghasilan bruto dikenakan kepada pegawai dengan golongan III.

c. $15 \%$ dari penghasilan bruto dikenakan kepada pegawai dengan golongan IV.

\section{Contoh Perhitungan PPh Pasal 21 Yang Dipotong Bendahara Pemerintah}

\section{Perhitungan PPh Pasal 21 yang Bersifat Tidak Final}

Perhitungan pemotongan $\mathrm{PPh}$ Pasal 21 terhadap pegawai tetap yang menerima tunjangan pajak dikutip dari Mardiasmo (2013 : 226) adalah sebagai berikut :

Pak Auriga merupakan PNS pada Inspektorat Daerah Kabupaten Minahasa Selatan. Penghasilan per bulan yang didapat terdiri dari gaji pokok sebesar Rp.3.112.900, tunjangan istri sebesar Rp.289.055, tunjangan anak sebesar Rp.115.622, tunjangan struktural sebesar Rp. 195.000, dan tunjangan beras sebesar Rp. 279.040. Perhitungan PPh Pasal 21 yang terutang untuk Pak Auriga adalah sebagai berikut :

Penghasilan :

Gaji Pokok

Rp. 3.112.900

Tunjangan Istri

Rp. $\quad 289.055$

Tunjangan Anak

Rp. 115.622

Tunjangan Struktural

Rp. $\quad 195.000$

Tunjangan Beras

Rp. 279.040

Tunjangan lain-lain

Rp. $\quad 1.128$

Penghasilan Bruto

Rp. 3.992 .745

Pengurangan:

Biaya Jabatan/Biaya Pensiun

Rp. $\quad 199.585$

Iuran Pensiun/Iuran THT

Rp. 167.084

(Rp. 366.168) 
Penghasilan Neto Sebulan

Rp. 3.626.076

Penghasilan Neto Setahun

Rp.43.512.912

Penghasilan Tidak Kena Pajak (PTKP)

Wajib Pajak (WP) sendiri

Rp.54.000.000

Wajib Pajak Kawin

Rp. 4.500 .000

Anak/Tanggungan (2)

Rp. 9.000 .000

Penghasilan Kena Pajak

PPh Pasal 21 Terutang

Rp.67.500.000
Rp. 0
Nihil

Jadi PPh Pasal 21 yang terutang atas penghasilan yang diterima oleh Pak Auriga adalah nihil, karena penghasilan Pak Auriga berada dibawah jumlah PTKP.

\section{Perhitungan PPh Pasal 21 yang Bersifat Final}

Pada bulan Agustus Pak Auriga menerima honorarium atas kegiatan monitoring yang dilakukan oleh Inspektorat Daerah Kabupaten Minahasa Selatan. Honorarium yang diterima adalah berupa uang pemeriksaan yang diterima sejumlah Rp.2.000.000. Pak Auriga adalah PNS dengan golongan III D. Maka perhitungan PPh Pasal 21 yang terutang adalah :

$\mathrm{PPh}$ Pasal $21=$ Penghasilan Bruto $\mathrm{x}$ Tarif Final (disesuaikan dengan golongan pegawai yang bersangkutan)

PPh Pasal $21=$ Rp. $2.000 .000 \times 5 \%$

$$
=\text { Rp.100.000,- }
$$

Jadi PPh Pasal 21 yang terutang atas honorarium yang diterima oleh Pak Auriga adalah sebesar Rp.100.000,-. Atas pemotongan yang dilakukan, maka bendahara pengeluaran wajib membuat bukti potong PPh Pasal 21. Bukti potong untuk PPh Pasal 21 yang bersifat final adalah berupa formulir 1721-VII, sedangkan untuk PPh Pasal 21 yang bersifat tidak final adalah berupa formulir 1721-A2.

\section{Pemotongan PPh Pasal 21}

Pemotongan PPh pasal 21 dilakukan saat pembayaran penghasilan kepada pegawai yang bersangkutan. Setelah dilakukan pemotongan PPh Pasal 21, bendahara pemerintah wajib memberikan bukti potong berupa formulir 1721-VII untuk pajak yang bersifat final dan 1721 - A2 untuk pajak yang bersifat tidak final.

Tata Cara Penyetoran dan Pelaporan PPh Pasal 21. Sesuai dengan Peraturan Direktur Jenderal Pajak Nomor PER-16/PJ/2016, bendahara pemerintah wajib menyetorkan dan melaporkan PPh Pasal 21 terutang untuk setiap bulan kalender. Dalam hal jumlah yang dipotong pada bulan yang bersangkutan adalah nihil bendahara pemerintah tetap diharuskan untuk melaporkan pajak.

Tabel 3 Batas Waktu Penyetoran dan Pelaporan PPh Pasal 21 Berdasarkan Peraturan Dirjen Pajak Nomor PER 16/PJ/2016

\begin{tabular}{|c|c|l|l|}
\hline No & \multicolumn{1}{|c|}{ Uraian } & \multicolumn{1}{|c|}{ Batas Setor/Bayar } & \multicolumn{1}{c|}{ Batas Lapor } \\
\hline 1 & SPT Masa PPh Pasal 21 & $\begin{array}{l}\text { paling lambat tanggal } \\
10 \text { bulan takwim } \\
\text { berikutnya setelah } \\
\text { Masa Pajak } \\
\text { berakhir. }\end{array}$ & $\begin{array}{l}\text { paling lambat 20 } \\
\text { hari setelah Masa } \\
\text { Pajak berakhir }\end{array}$ \\
\hline 2 & SPT Tahunan PPh Pasal 21 & $\begin{array}{l}\text { sebelum SPT } \\
\text { tahunan } \\
\text { disampaikan. }\end{array}$ & $\begin{array}{l}\text { akhir bulan ketiga setelah } \\
\text { berakhirnya tahun pajak }\end{array}$ \\
\hline
\end{tabular}


Surat Setoran Pajak. Surat Setoran Pajak (SSP) adalah bukti berupa formulir untuk membayar atau menyetor pajak yang dilakukan atau telah dilakukan dengan cara lain ke kas negara melalui bank atau kantor pos. Sesuai dengan PER-26/PJ/2014 tentang Sistem Pembayaran Secara Elektronik mengharuskan bahwa wajib pajak dapat melakukan pembayaran atau penyetoran pajak dengan sistem pembayaran pajak secara elektronik. Transaksi pembayaran atau penyetoran pajak dapat dilakukan melalui bank atau kantor pos dengan menggunakan kode billing.

Surat Pemberitahuan (SPT). Surat Pemberitahuan (SPT) adalah formulir yang digunakan untuk melaporakan pajak yang telah dibayar dan disetorkan. Sesuai dengan PER-03/PJ/2015 tentang Penyampaian Surat Pemberitahuan Elektronik, maka wajib pajak dapat menyampaikan SPT secara elektronik melalui aplikasi e-filling.

\section{Penelitian Terdahulu}

1. Gosal (2017) dengan judul "Analisis Perhitungan dan Pelaporan Pajak Penghasilan Pasal 21 Wajib Pajak Orang Pibadi Pada Badan Pengelola Keuangan dan Aset Daerah Kota Manado". Tujuan dari penelitian ini yaitu mengetahui perhitungan pajak penghasilan pasal 21 pegawai tetap pada Badan Pengelola Keuangan dan Aset Daerah (BPKAD) Kota Manado dan membandingkan dengan Peraturan Menteri Keuangan No. 101 /PMK.010/2016 tentang Penyesuaian Besarnya Penghasilan Tidak Kena Pajak (PTKP); dan membandingkan dengan Peraturan Direktur Jenderal Pajak Nomor : PER 31/PJ/2012 tentang Pedoman Teknis Tata Cara Penyetoran dan Pelaporan Pajak Penghasilan Pasal 21 Sehubungan Dengan Pekerjaan, Jasa, dan Kegiatan Orang Pribadi. Metode penelitian yang digunakan adalah kualitatif. Hasil penelitian menunjukkan bahwa perhitungan PPh Pasal 21 yang dilakukan belum sesuai karena jumlah yang diinput terjadi kelebihan dana, sedangkan untuk perhitungan PTKP, penyetoran PPh pasal 21 telah sesuai dengan ketentuan, untuk pelaporan pajak PPh Pasal 21 juga belum sesuai dengan ketentuan. Persamaan penelitian ini dengan penelitian yang dilakukan oleh penulis adalah keduanya meneliti tentang PPh Pasal 21 pada Instansi Pemerintah, sedangkan perbedaannya adalah pada objek penelitian.

2. Tumbel (2017) dengan judul "Evaluasi Mekanisme Pemotongan dan Pelaporan Pajak oleh Bendaharawan Pemerintah Pada Badan Perencanaan Penelitian dan Pembangunan Minahasa Selatan". Tujuan dari penelitian ini adalah Untuk mengetahui bagaimana proses pemotongan pajak oleh bendaharawan pemerintah di Badan Perencanaan Penelitian dan Pembangunan Kabupaten Minahasa Selatan dan Untuk mengetahui bagaimana proses pelaporan pajak oleh bendahara pemerintah Badan Perencanaan Penelitian dan Pembangunan Kabupaten Minahasa Selatan.Metode penelitian yang digunakan adalah deskriptif. Hasil penelitian menunjukkan bahwa pemotongan dan pelaporan pajak yang dilakukan telah sesuai dengan ketentuan yang berlaku. Persamaan penelitian ini dengan penelitian yang dilakukan oleh penulis adalah keduanya meneliti tentang PPh Pasal 21 pada Instansi Pemerintah, sedangkan perbedaannya adalah pada objek penelitian.

\section{METODE PENELITIAN}

Jenis Penelitian. Jenis penelitian yang digunakan pada penelitian ini adalah penelitian kualitatif. Pada penelitian ini penulis akan mengamati penerapan PPh Pasal 21 pada Inspektorat Daerah Kabupaten Minahasa Selatan kemudian mengevaluasi kesesuaian penerapan tersebut dengan PMK Nomor 262/ PMK 03 Tahun 2010 dan Peraturan Dirjen Pajak Nomor 16/ PJ/ 2016.

Tempat dan Waktu Penelitian. Penelitian ini dilaksanakan pada Inspektorat Daerah Kabupaten Minahasa Selatan yang beralamat, di Kelurahan Lopana, Kecamatan Amurang 
Timur, Minahasa Selatan, Sulawesi Utara. Penelitian ini dimulai pada bulan April 2018 dan selesai pada bulan Mei 2018.

Jenis Data. Jenis data yang ada pada penelitian ini, yaitu:

1. Data Kualitatif

Data kualitatif dalam penelitian ini adalah data yang diperoleh dari hasil wawancara dengan bendahara pegeluaran Inspektorat Daerah Kabupaten Minahasa Selatan yang dapat memberikan informasi mengenai kegiatan perhitungan, penyetoran dan pelaporan PPh Pasal 21.

2. Data Kuantitatif

Data kuantitatif dalam penelitian ini adalah daftar gaji pegawai, buku kas umum bendahara pengeluaran, bukti potong PPh Pasal 21, SPT PPh Pasal 21, struktur organisasi, dan profil instansi.

Sumber Data. Sumber data pada penelitian ini, yaitu:

1. Data Primer

Data primer dalam penelitian ini adalah data yang diperoleh dari hasil wawancara dengan bendahara pengeluaran Inspektorat Daerah Kabupaten Minahasa Selatan untuk mengetahui objek-objek yang dipotong PPh Pasal 21 dan mekanisme perhitungan, penyetoran dan pelaporan PPh Pasal 21.

2. Data Sekunder

Data sekunder dalam penelitian ini adalah data yang diperoleh dari dokumen - dokumen Inspektorat Daerah Kabupaten Minahasa Selatan seperti daftar gaji pegawai, buku kas umum bendahara pengeluaran, bukti potong PPh Pasal 21, SPT PPh Pasal 21, struktur organisasi, dan profil instansi serta data yang berasal dari studi kepustakaan dengan mempelajari buku - buku yang berkaitan dengan masalah yang diteliti.

\section{Metode Pengumpulan data}

1. Studi Dokumentasi

2. Wawancara

Metode dan Proses Analisis. Metode analisis yang digunakan dalam penelitian adalah metode analisis deskriptif. Adapun langkah - langkah untuk menganalisis data yang dilakukan oleh peneliti adalah sebagai berikut :

1. Melakukan evaluasi tentang objek PPh Pasal 21 berdasarkan PMK Nomor 262/PMK.03 Tahun 2010 yang dipotong oleh Inspektorat Daerah Kabupaten Minahasa Selatan, dengan cara menginventarisir semua transaksi - transaksi instansi yang merupakan objek $\mathrm{PPh}$ Pasal 21 untuk melihat objek PPh Pasal 21 yang telah dipotong ataupun tidak dipotong oleh Inspektorat Daerah Kabupaten Minahasa Selatan.

2. Melakukan evaluasi perhitungan PPh Pasal 21 yang dilakukan oleh Inspektorat Daerah Kabupaten Minahasa Selatan untuk menguji kesesuaian perhitungan tersebut dengan ketentuan pada PMK 262/PMK 0.3 Tahun 2010.

3. Melakukan evaluasi tentang cara penyetoran dan pelaporan PPh Pasal 21 yang dilakukan oleh Inspektorat Daerah Kabupaten Minahasa Selatan berdasarkan Peraturan Dirjen Pajak Nomor 16/PJ/2016.

\section{HASIL PENELITIAN DAN PEMBAHASAN}

\subsection{Hasil Penelitian}

Objek Yang Dilakukan Pemotongan PPh Pasal 21. Pemotongan PPh Pasal 21 yang dilakukan oleh Bendahara Pengeluaran Inspektorat Daerah Kabupaten Minahasa Selatan terbagi atas dua jenis, yaitu :

1. Pemotongan PPh Pasal 21 yang bersifat final, hanya dikenakan atas penghasilan yang bersifat tidak tetap atau tidak teratur berupa honorarium atau imbalan tidak tetap dan 
tidak teratur lainnya dengan nama dan dalam bentuk apapun yang menjadi beban APBN/APBD yang dibayarkan pada PNS.
a. Tunjangan Beban Kerja (TBK)
b. Uang Pemeriksaan
c. Honorarium Pengelola Keuangan:

1. Honorarium Pejabat pembuat komitmen (PPK)

2. Honorarium pejabat penatausahaan keuangan (PPK SKPD)

3. Honorarium Bendahara Pengeluaran

4. Honorarium Penerima Barang

5. Honorarium pengurus barang

d. Honorarium Kegiatan. Honorarium Panitia Pelaksana kegiatan Majelis Pertimbangan Tuntutan Perbendaharaan dan Tuntutan Ganti Rugi (MPTPTGR)

e. Honorarium tenaga ahli

2. Pemotongan PPh Pasal 21 yang bersifat tidak final dikenakan atas:

a. Penghasilan yang diterima secara tetap dan teratur yaitu gaji dan tunjangan yang diterima setiap bulan.

b. Gaji -13

c. Tunjangan Hari Raya (THR). PPh Pasal 21 yang bersifat tidak final dikenai tarif Pasal 17 UU PPh.

Tata Cara Perhitungan PPh Pasal 21

Perhitungan PPh Pasal 21 pada Inspektorat Daerah Kabupaten Minahasa Selatan adalah sebagai berikut :

Untuk pegawai A yang belum menikah

Pegawai A (Penata Tk. I / III/d)

Penghasilan :

Gaji Pokok

Rp. 3.381 .750

Tunjangan Struktural

Rp. $\quad 585.000$

Tunjangan Beras

Rp. $\quad 69.760$

Tunjangan lain-lain

Rp. $\quad 130$

Penghasilan Bruto

Rp. 4.035 .890

Pengurangan:

Biaya Jabatan/Biaya Pensiun

Rp. 201.830

Iuran Pensiun/Iuran THT

Rp. 160.640

Penghasilan Neto Sebulan

Penghasilan Neto Setahun

Penghasilan Tidak Kena Pajak (PTKP)

Wajib Pajak (WP) sendiri

Penghasilan Kena Pajak

PPh Pasal 21 Terutang

(Rp. 362.470)

Rp. 3.673 .420

Rp.44.081.040

(Rp.54.000.000)

Rp. 0

Nihil

\section{Perhitungan PPh Pasal 21 atas Gaji-13 yang diterima Pegawai B}

Penghasilan :

Gaji Pokok

Rp. 3.789 .683

Tunjangan Istri

Rp. $\quad 351.899$

Tunjangan Anak

Rp. $\quad 70.380$

Tunjangan Struktural

Rp. 1.365 .000

Tunjangan Beras

Rp. $\quad 209.280$

Tunjangan lain-lain

Rp. $\quad 437$

Gaji Pokok dan Tunjangan Sebulan

Rp. 5.786.242 


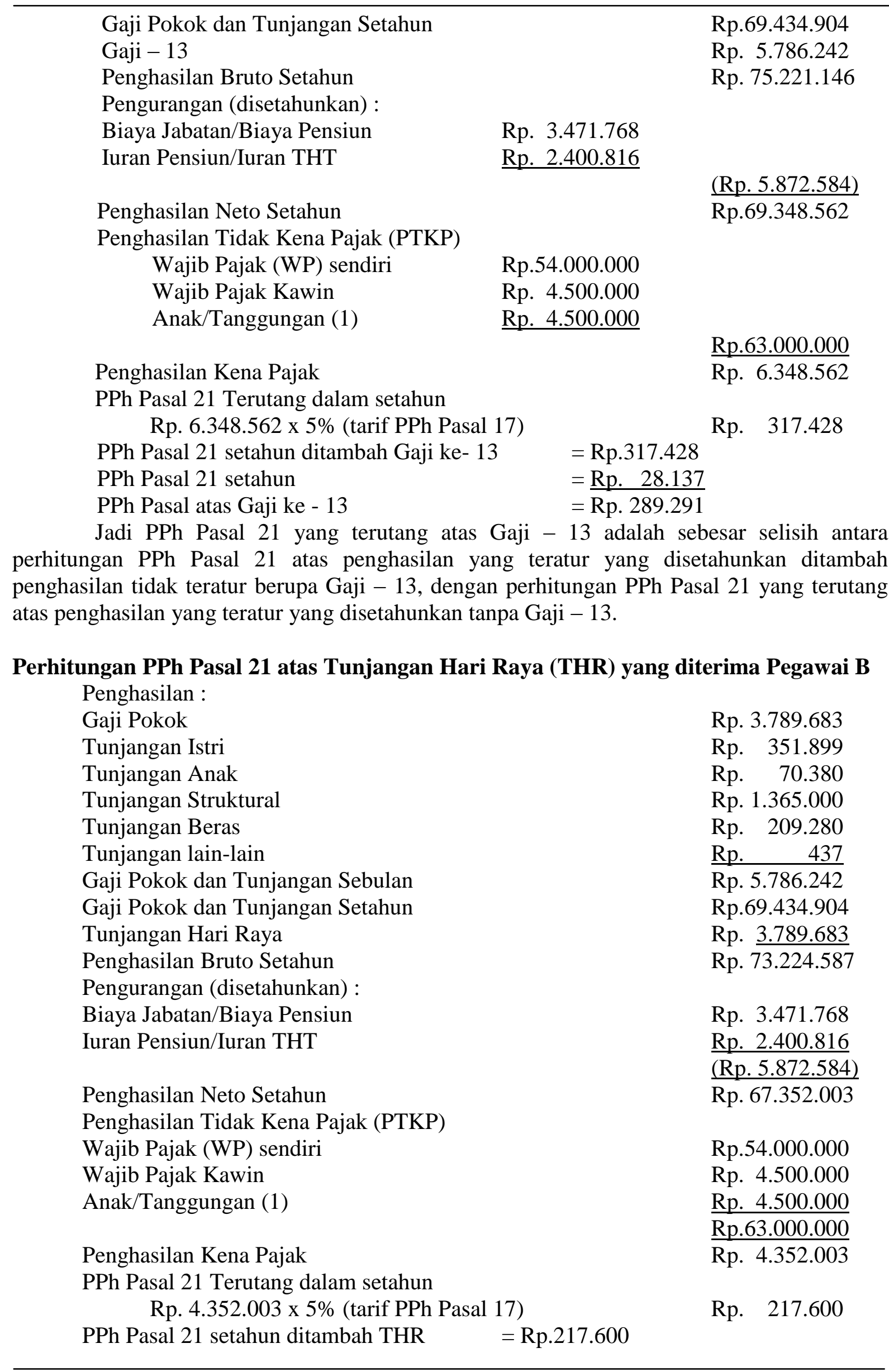


PPh Pasal 21 setahun

$\mathrm{PPh}$ Pasal atas THR

$$
\begin{aligned}
& =\underline{\text { Rp. } .28 .137} \\
& =\text { Rp. } 189.463
\end{aligned}
$$

Tabel 4. Perhitungan Dan Pemotongan PPh Pasal 21 Yang bersifat Final

\begin{tabular}{|c|l|l|c|c|c|}
\hline Nama & Golongan & Honorarium & Tarif & Sifat & PPh Terutang \\
\hline E & II/c & Rp.2.000.000 & $0 \%$ & Final & Nihil \\
\hline F & III/d & RP.3.000.000 & $5 \%$ & Final & Rp.150.000 \\
\hline G & IV/b & Rp.4.500.000 & $15 \%$ & Final & Rp.675.000 \\
\hline \multicolumn{5}{|l}{} & \\
\hline
\end{tabular}

Sumber: Inspektorat Daerah Kabupaten Minahasa Selatan

Tata Cara Pemotongan PPh Pasal 21. Bendahara Pengeluaran Inspektorat Daerah Kabupaten Minahasa Selatan melakukan pemotongan PPh pasal 21 hanya pada pembayaran penghasilan yang tidak tetap dan tidak teratur berupa honorarium dan imbalan dengan memberikan bukti potong PPh Pasal 21 kepada pegawai menggunakan formulir 1721-VII, untuk pajak yang bersifat tidak final yang dikenakan atas penghasilan tetap dan teratur bendahara pengeluaran tidak melakukan pemotongan PPh Pasal 21 karena untuk penghasilan yang tetap dan teratur pajaknya ditanggung oleh pemerintah, namun bendahara pengeluaran tetap membuat bukti pemotongan PPh Pasal 21 yang bersifat tidak final berupa formulir 1721-A2 untuk keperluan pelaporan pajak pada SPT Tahunan pegawai.

Tata Cara Penyetoran PPh Pasal 21. Penyetoran pajak PPh Pasal 21 pada Inspektorat Daerah Kabupaten Minahasa Selatan menggunakan Billing System, yaitu dengan mengisi data pada akun e-billing kemudian mencetak kode billing dan melakukan pembayaran di kantor Pos atau di Bank menggunakan kode billing tersebut.

Tabel 5. Penyetoran Pajak Final yang Dilakukan Oleh Inspektorat Daerah Kabupaten Minahasa selatan untuk Masa Pajak bulan Agustus sampai Bulan November 2017

\begin{tabular}{|c|c|c|l|}
\hline $\begin{array}{c}\text { Masa } \\
\text { Pajak }\end{array}$ & $\begin{array}{c}\text { Tanggal } \\
\text { Penyetoran } \\
\text { Pajak }\end{array}$ & $\begin{array}{c}\text { Jumlah Pajak } \\
\text { yang Disetor }\end{array}$ & \multicolumn{1}{|c|}{ Uraian } \\
\hline $08 / 08 / 2017$ & $16 / 08 / 2017$ & Rp.425.000 & $\begin{array}{l}\text { PPh Pasal 21 pembayaran belanja } \\
\text { perjalanan dinas dalam daerah mengadakan } \\
\text { pemeriksaan khusus audit laporan keuangan } \\
\text { PDAM a.n Steven Kumarurung,Cs }\end{array}$ \\
\hline $10 / 10 / 2017$ & $31 / 10 / 2017$ & Rp.465.000 & $\begin{array}{l}\text { PPh Pasal 21 mengadakan monitoring tndak } \\
\text { lanjut }\end{array}$ \\
\hline $11 / 11 / 2017$ & $23 / 11 / 2017$ & Rp.225.000 & $\begin{array}{l}\text { PPh 21 belanja perjalanan dinas dalam } \\
\text { daerah mengadakan monitoring indak } \\
\text { lanjut hasil temuan BPK RI Perwakilan } \\
\text { allut Thn. 2016-2017 a.n Steven } \\
\text { Kumarurung }\end{array}$ \\
\hline
\end{tabular}

Tata Cara Pelaporan PPh Pasal 21. Pada Inspektorat Daerah Kabupaten Minahasa Selatan setelah dilakukan pemotongan PPh Pasal 21 yang bersifat final selanjutnya tidak dilakukan pelaporan PPh pasal 21 dengan alasan bahwa jenis pajak yang dipotong adalah final jadi tidak perlu dilaporkan lagi. Sedangkan untuk Pajak PPh Pasal 21 yang bersifat tidak final bendahara hanya mengisi data pegawai yang terdiri dari gaji, tunjangan, status perkawinan, jumlah tanggungan, harta dan kewajiban pada aplikasi e-SPT dan selanjutnya masing masing pegawai akan melaporkan kewajiban perpajakannya melalui $e$-filling. 


\subsection{Pembahasan}

Analisis Penetapan Objek PPh Pasal 21 di Inspektorat Daerah Kabupaten Minahasa Selatan. Jika dilihat dari objek - objek yang dipotong PPh Pasal 21 oleh Inspektorat Daerah Kabupaten Minahasa Selatan, maka dapat dikatakan bahwa objek - objek tersebut telah sesuai dengan katentuan yang diatur dalam PMK.262/PMK.03 Tahun 2010 dan PP No. 80 Tahun 2010. Selanjutnya setelah dilakukan identifikasi pada Buku Kas Umum Bendahara Pengeluaran, selain objek - objek yang telah dipotong PPh Pasal 21 seperti yang telah dirincikan sebelumnya, ada juga objek PPh Pasal 21 yang tidak dipotong pajak, yaitu pembayaran gaji tenaga kerja non pegawai atau pembayaran gaji tenaga kontrak non pegawai. Dihubungkan dengan Peraturan Direktur Jenderal Pajak No. PER 16/PJ/, maka pembayaran atas gaji tenaga kerja non pegawai atau pembayaran gaji tenaga kontrak non pegawai pada Inspektorat Daerah Kabupaten Minahasa Selatan memang tidak perlu dilakukan pemotongan $\mathrm{PPh}$ Pasal 21 karena yang dibayarkan kepada tenaga kerja non pegawai atau tenaga kontrak non pegawai yaitu dibawah penghasilan tidak kena pajak (PTKP), maka tidak perlu dilakukan pemotongan PPh Pasal 21.

Analisis Perhitungan PPh Pasal 21 di Inspektorat Daerah Kabupaten Minahasa Selatan. Berdasarkan hasil penelitian pada bagian sebelumnya, maka perhitungan $\mathrm{PPh}$ Pasal 21 pada Inspektorat Daerah Kabupaten Minahasa Selatan jika dikaitkan dengan syarat syarat diatas maka mekanisme perhitungannya adalah sebagai berikut :

1. Tarif Pajak Penghasilan Pasal 21

a. Tarif Final, untuk penghasilan yang diterima secara tidak tetap dan tidak teratur yaitu $0 \%$ untuk golongan I dan II, 5\% untuk golongan III dan 15\% untuk golongan IV.

b. Tarif Progresif sesuai dengan pasal 17 UU Pajak Penghasilan yang dikenakan atas penghasilan yang bersifat tetap pada setiap bulan berupa gaji dan tunjangan.

2. Tata Cara Perhitungan PPh Pasal 21

a. Untuk Penghasilan yang dibayarkan secara tetap dan teratur untuk setiap bulan:

1. Penghasilan bruto adalah jumlah gaji pokok ditambah dengan tunjangan istri, tunjangan anak, tunjangan struktural/fungsional dan tunjangan beras.

2. Pengurangan dalam perhitungan $\mathrm{PPh}$ Pasal 21 adalah biaya jabatan sebesar 5\% dari penghasilan bruto dan iuran pensiun.

3. Penghasilan neto adalah sebesar penghasilan bruto dikurangi dengan pengurangan PPh Pasal 21 ( biaya jabatan dan iuran pensiun).

4. Penghasilan Tidak Kena Pajak (PTKP) adalah sebesar Rp.54.000.000 / tahun untuk WPOP Rp.4.500.000 / tahun tambahan untuk WP kawin, dan Rp.4.500.000 / tahun tambahan untuk setiap tanggungan (hingga 3 tanggungan).

5. Penghasilan kena pajak (PKP) didapat dari penghasilan neto setahun dikurangi dengan PTKP.

6. PPh Pasal 21 yang terutang adalah sebesar Penghasilan Kena Pajak (PKP) dikali dengan tarif progresif Pasal 17 UU Pajak Penghasilan.

b. Untuk penghasilan yang dibayarkan berupa Gaji - 13 dan THR, perhitungannya adalah sebesar selisih antara perhitungan PPh Pasal 21 atas penghasilan yang teratur yang disetahunkan ditambah penghasilan tidak teratur berupa Gaji -13 dan THR, dengan perhitungan PPh Pasal 21 yang terutang atas penghasilan yang teratur yang disetahunkan tanpa Gaji - 13 dan THR.

c. Untuk penghasilan yang dibayarkan secara tidak tetap dan tidak teratur, yaitu berupa tunjangan beban kerja, uang pemeriksaan, honorarium pejabat pembuat komitmen (PPK), honorarium penatausahaan keuangan (PPK SKPD), honorarium bendahara pengeluaran, honorarium pengurus barang, honorarium penerima barang dan honorarium tenaga ahli. Perhitungan $\mathrm{PPh}$ Pasal 21 yang terutang adalah sebesar 
penghasilan bruto dikali dengan tarif final yang disesuaikan dengan golongan pegawai yang bersangkutan.

Analisis Pemotongan Pajak Penghasilan Pasal 21. Pemotongan PPh Pasal 21 yang dipotong oleh bendahara pengeluaran jika disesuaikan dengan PMK 262/PMK.03 Tahun 2010 dan Perdirjen Nomor 16/PJ/2016, maka dapat dikatakan sudah sesuai karena untuk penghasilan yang dibayarkan secara tetap pada setiap bulan diberikan bukti potong PPh Pasal 21 berupa formulir $1721 \mathrm{~A} 2$, sedangkan untuk penghasilan tidak teratur yang dipotong $\mathrm{PPh}$ Final, diberikan bukti potong berupa formulir 1721-VII.

Analisis Penyetoran dan Pelaporan PPh Pasal 21. Sesuai dengan PMK 262/PMK.03 Tahun 2010 dan Perdirjen Nomor 16/PJ/2016 bahwa penyetoran PPh Pasal 21 dapat dilakukan di Kantor Pos dan Bank dan sesuai dengan PER-26/PJ/2014 bahwa penyetoran harus menggunakan kode billing dan ketentuan ini telah diterapkan oleh Inspektorat Daerah Kabupaten Minahasa Selatan. Untuk penerapan pelaporan PPh Pasal 21, Inspektorat Daerah Kabupaten Minahasa Selatan tidak melakukan pelaporan pajak yang bersifat final. Sedangkan pada pajak PPh Pasal 21 yang bersifat tidak final pelaporan pajak tidak perlu dilakukan karena pajaknya ditanggung oleh pemerintah.

\section{KESIMPULAN DAN SARAN}

\subsection{Kesimpulan}

berikut:

Berdasarkan pembahasan tersebut, maka kesimpulan penelitian ini adalah sebagai

1. Penetapan objek PPh Pasal 21 di Inspektorat Daerah Kabupaten Minahasa Selatan sudah sesuai dengan PMK 262/PMK.03 Tahun 2010 dan PP No. 80 Tahun 2010.

2. Perhitungan PPh Pasal 21 di Inspektorat Daerah Kabupaten Minahasa Selatan sudah sesuai PMK 262/PMK.03 Tahun 2010 dan Peraturan Dirjen Pajak Nomor 16/PJ/2016.

3. Pemotongan PPh Pasal 21 yang dilakukan oleh Inspektorat Daerah Kabupaten Minahasa Selatan sudah sesuai dengan ketentuan pada Peraturan Direktur Jenderal Pajak Nomor PER - 16/PJ/2016 dan PMK Nomor 262/PMK.03 Tahun 2010.

4. Penyetoran Pajak PPh Pasal 21 di Inspektorat Daerah Kabupaten Minahasa Selatan sudah sesuai dengan ketentuan pada Peraturan Direktur Jenderal Pajak Nomor PER 16/PJ/2016.

5. Pelaporan Pajak Penghasilan Pasal 21 pada Inspektorat Daerah Kabupaten Minahasa Selatan belum sesuai dengan ketentuan pada Peraturan Direktur Jenderal Pajak Nomor PER - 16/PJ/2016 karena bendahara pengeluaran tidak melakukan pelaporan Pajak PPh Pasal 21.

\subsection{Saran}

Saran yang dapat penulis berikan untuk Inspektorat Daerah Kabupaten Minahasa Selatan berdasarkan pembahasan tersebut adalah sebagai berikut :

1. Bendahara pengeluaran harus melaporkan pemotongan pajak untuk setiap bulan, walaupun pada bulan yang bersangkutan tidak terjadi pemotongan pajak PPh Pasal 21. Hal ini adalah untuk memenuhi ketentuan pada Peraturan Direktur Jenderal Pajak Nomor PER - 16/PJ/2016.

2. Bendahara Pengeluaran harus melaporkan pemotongan pajak $\mathrm{PPh}$ Pasal 21 yang bersifat final, agar tidak terkena sanksi administrasi sebesar Rp.100.000 sesuai pada pasal 7 UU KUP.

\section{DAFTAR PUSTAKA}

Direktorat Jenderal Pajak. 2016. Bendahara Mahir Pajak. Tim Penyusun Direktorat Peraturan Perpajakan II 2016. Jakarta. 
Gosal, Y., Karamoy H. dan Warongan J.D.L.2017. Analisis Perhitungan dan Pelaporan Pajak Penghassilan Pasal 21 Wajib Pajak Orang Pribadi Pada Badan Pengelola Keuangan Dan Aset Daerah Kota Manado. Jurnal Riset Akuntansi Going Concern. Unsrat. Manado.

Mardiasmo. 2013. Perpajakan Edisi Revisi. Andi: Yogyakarta.

Peraturan Pemerintah Nomor 80 tahun 2010 Tentang Tarif Pemotongan dan Pengenaan Pajak Penghasilan Pasal 21 atas Penghasilan Yang Menjadi Beban APBN/APBD.

Peraturan Menteri Keuangan Nomor 262/PMK.03 Tahun 2010 Tentang Tata Cara Pemotongan Pajak Penghasilan Pasal 21 Bagi Pejabat Negara PNS, Anggota TNI, Anggota POLRI, dan Pensiunannya atas Penghasilan Yang Menjadi Beban APBN/APBD.

Peraturan Menteri Keuangan Nomor 101/PMK.010/2016 Tentang Penyesuaian Penghasilan Tidak Kena Pajak.

Peraturan Direktur Jenderal Pajak No. PER 16/PJ/2016 Tentang Pedoman Teknis Tata Cara Pemotongan, Penyetoran, dan Pelaporan PPh Pasal 21 dan/atau PPh Pasal 26 Sehubungan dengan Pekerjaan, Jasa dan Kegiatan Orang Pribadi.

Sugiyono. 2013. Metode Penelitian Bisnis. Bandung: Alfabeta.

Supriyanto, E. 2011. Akuntansi Perpajakan. Graha Ilmu. Yogyakarta.

Sujarweni, W. 2014. Metedologi Penelitian. Pusat Baru Press. Yogyakarta.

Tumbel, A., Karamoy H. Dan Tirayoh V. 2017. Evaluasi Mekanisme Pemotongan dan Pelaporan Pajak Oleh Bendaharawan Pemerintah Pada Badan Perencanaan Penelitian dan Pembangunan Kabupaten Minahasa Selatan. Jurnal Riset Akuntansi Going Concern. Unsrat. Manado.

Undang - Undang Nomor 36 Tahun 2008 Perubahan Keempat Atas Undang - Undang Nomor 7 Tahun 1983 Tentang Pajak Penghasilan. 